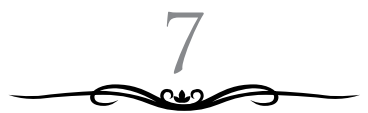

\title{
PEMANFAATAN PERPUSTAKAAN UNTUK MENINGKATKAN MOTIVASI MEMBACA MAHASISWA STAIN KUDUS
}

\author{
Retno Susilowati \\ STAIN Kudus, Jawa Tengah, Indonesia \\ luqyana02@gmail.com
}

\begin{abstract}
The word in the English language library or library comes from the Latin meaning librarium collection of books only. But as the times then in the library already available tapes, CDs, slides, films, microfilm, and so on. Library is in need of technology in management, so as to serve visitors with fast and fun.In the era of modernization and sophisticated technology, the development of the Internet, the use of smart phones, a computer program then the rapid development of information so obtained. Therefore the role of the library not only provides a collection of digital and non-digital, but also must provide an online library, electronic library so that there is a shift of functions from processing library collection into a data processing, further processing of information and ultimately knowledge processing. Use of the library in a good college, can increase student motivation to read. Hope for the future, the library is getting better service to visitors and provides a comfortable place, and is able to provide fast, to support the needs of visitors.
\end{abstract}

Keywords: Library, Motivation, Reading. 


\begin{abstract}
Abstrak
Kata perpustakaan atau dalam bahasa Inggris library berasal dari bahasa Latin librarium yang berarti kumpulan bukubuku saja. Tetapi seiring perkembangan zaman maka di perpustakaan sudah tersedia kaset, CD, slide, film, microfilm, dan sebagainya. Perpustakaan sangat memerlukan teknologi dalam pengelolaannya, sehingga dapat melayani pengunjung dengan cepat dan menyenangkan. Di era modernisasi dan teknologi serba canggih, yaitu berkembangnya internet, penggunaan handphone smart, program komputer maka perkembangan informasibegitu cepat didapat. Oleh karena itu, peran perpustakaan tidak hanya menyediakan koleksi digital dan non digital, tetapi juga harus menyediakan perpustakaan online, perpustakaan elektronik sehingga terjadi pergeseran dari fungsi dari perpustakaan pengolah koleksi menjadi pengolah data, selanjutnya pengolah informasi dan pada akhirnya pengolah pengetahuan. Pemanfaatan perpustakaan di perguruan tinggi yang baik, dapat meningkatkan motivasi membaca mahasiswa. Harapan untuk ke depan, perpustakaan semakin lebih baik dalam pelayanan kepada pengunjung dan menyediakan tempat yang nyaman, serta mampu menyediakan layanan yang cepat, untuk menunjang kebutuhan para pengunjung.
\end{abstract}

Kata Kunci: Perpustakaan, Motivasi, Membaca.

\title{
A. Pendahuluan
}

Kata perpustakaan atau dalam bahasa Inggris library berasal dari bahasa Latin librarium yang berarti kumpulan buku-buku saja. Tetapi seiring perkembangan zaman maka di perpustakaan sudah tersedia kaset, CD, slide, film, microfilm dan sebagainya. Perpustakaan sangat memerlukan teknologi dalam pengelolaannya, sehingga dapat melayani pengunjung dengan cepat dan menyenangkan.

Di era modernisasi dan teknologi serba canggih, yaitu berkembangnya internet, penggunaan handphone smart, program komputer maka perkembangan informasi begitu cepat didapat. Oleh karena itu, peran perpustakaan tidak hanya menyediakan 
koleksi digital dan non digital, tetapi juga harus menyediakan perpustakaan online, perpustakaan elektronik sehingga terjadi pergeseran dari fungsi dari perpustakaan pengolah koleksi menjadi pengolah data, selanjutnya pengolah informasi dan pada akhirnya pengolah pengetahuan.

Apabila fungsi perpustakaan dapat seperti di atas maka tidak akan diragukan lagi bahwa antusiasme mahasiswa untuk membaca semakin tinggi, sehingga dapat mendukung dalam proses perkuliahan. Informasi yang akan didapat mahasiswa semakin cepat, sehingga tugas-tugas mata kuliah juga akan semakin cepat pula untuk diselesaikan.

\section{B. Pembahasan}

\section{Pengertian Motivasi}

Menurut Mustofa Halmar secara bahasa motivasi berasal dari bahasa Inggris motivation, yang kata kerjanya adalah motivate yang berarti to provide with motives, as the characters in a story or play (sebagai karakter dalam cerita atau permainan) yang dalam kamus Bahasa Indonesia berarti sebab-sebab yang menjadi dorongan bagi tindakan manusia. ${ }^{1}$

Menurut Sumadi Suryabrata, motif adalah keadaan dalam pribadi orang yang mendorong individu untuk melakukan aktivitasaktivitas tertentu guna mencapai tujuan. ${ }^{2}$

Motivasi berasal dari kata motif yang mempunyai arti sebagai daya upaya yang mendorong seseorang untuk melakukan sesuatu. ${ }^{3}$

${ }^{1}$ Mustopa Halmar, Strategi Belajar Mengajar (Semarang: Universitas Islam Sultan Agung, 2006), hlm. 41.

2 Sumadi Suryabrata, Psikologi Pendidikan (Jakarta: RajaGrafindo Persada, 2004), hlm. 70.

3 Sardiman A.M., Interaksi dan Motifasi Belajar Mengajar (Jakarta: Rajawali Press,1988), hlm. 73. 


\section{Pengertian Membaca}

Membaca adalah suatu proses yang dilakukan serta dipergunakan oleh pembaca untuk memperoleh pesan, yang hendak disampaikan oleh penulis melalui media kata-kata/bahasa tulis. Suatu proses yang menuntutagar kelompok kata yang merupakan suatu kesatuan akan terlihat alam suatu pandangan sekilas dan makna-makna kata secara individual akan dapat diketahui. Kalau hal ini tidak terpenuhi, pesan yang tersurat dan yang tersirat tidak akan tertangkap atau dipahami, dan proses membaca itu tidak terlaksana dengan baik. ${ }^{4}$

Dari segi linguistik, membaca adalah suatu proses penyandingan dan pembacaan sandi (a recording and decoding prosess), berlainan dengan membaca dan menulisyang justru melibatkan penyandingan (encoding). Sebuah aspek pembacaan sandi (decoding) adalah menghubungkan kata-kata tulis (written word) dengan makana bahasa lisan (oral language meaning) yang mencakup perubahan tulisan/cetakan memnjadi bunyi yang bermakana. ${ }^{5}$

Istilah-istilah linguistik decoding dan encoding tersebuat akan mudah dimengerti kalau dapat memahami bahwa bahasa (language) adalah sandi (code) yang direncanakan untuk membawa/menganding makana (meaning). Kalu kita menyimak pembicara, pada dasarnya kita men-decode (membaca sandi) makna ujaran tersebut. Apabila kita berbicara, pada dasarnya kita men-decode(menyandingkan) bunyi-bunyi bahasa untuk membuat/ mengutarakan makna(meaning). Seperti juga halnya berbicara pada grafik, menulispun merupakan suatu proses penyandingan(encoding prosess), dan membaca sebagai suatu penafsiran atau interpretasi terhadap ujaran yang berada dalam bentuk tulisan adalah suatu proses pembacaan sandi (decoding prosess). Beberapa ahli lebih cenderung memakai istilah recording (membaca) sebab pertama

${ }^{4}$ FM Hodgson, Learning Modern Languages (London: Routledge \& Hegan Paul, t.t.), hlm. 43-44.

5 Anderson, Language Skills in Elementary Education (New York: MacMillan Publishing Co., Inc., 1972), hlm. 209-210. 
sekali lambing-lambang tertulis (written symbols) diubah menjadi bunyi, kemudian barulah sandi itu dibaca (are decoded). Menyimak dan membaca berhubungan erat karena keduanya merupakan alat untuk menerima komunikasi. Berbicara dan menulis berhubungan erat karena keduanya merupakan alat untuk mengutarakan makna, mengemukakan pendapat, mengekspresikan pesan. ${ }^{6}$

Di samping pengertian atau batasan yang telah diutarakan di atas, membaca pun dapat pula diartikan sebagai suatu metode yang kita pergunakan untuk berkomunikasi dengan diri kita sendiri dan kadang-kadang dengan orang lain-yaitu mengomunikasikan makna yang terkandung atau tersirat pada lambang-lambangtertulis. Bahkan, ada pula beberapa penulis yang seolah-seolah beranggapan bahwa "membaca" suatu kemampuan untuk melihat lambanglambang tertulis serta mengubah lambang-lambang tertulis tertulis tersebut melalui fonic ( phonics = suatu metode pengajaran membaca, ucapan ejaan berdasarkan interpretasi fonetik terhadap ejaan biasa) menjadi/menuju membaca lisan (oral readig). Tingkatan hubungan antara makna yang hendak dikemukakan oleh penulis dan penafsiran atau interpretasi pembaca turut menentukan ketepatan membaca. Makna bacaan tidak terletak pada halaman tertulis, tetapi pada pikiran pembaca. Demikianlah, makna itu akan berubah karena setiap pembaca memiliki pengalaman yang berbeda-beda yang di pergunakan sebagai alat untuk menginterpretasikan katakata tersebut.

Secara singkat reading adalah meaning to and getting meaning fron printed or written material, memetik serta memahami arti atau makna yang terkandung di dalam bahan tertulis. ${ }^{7}$ Jelaskan bagi kita bahwa membaca adalah suatu proses yang bersangkut paut dengan bahasa. Oleh karena itu, para pelajar haruslah dibantu untuk menanggapi atau memberi respons terhadap lambanglambang visual yang menggambarkan tanda-tanda oditori yang sama yang yang telah mereka tanggapi sebelum itu. Menyimak dan berbicara haruslah selalu mendahului kegiatan membaca. Ketika

\section{${ }^{6}$ Ibid., hlm. 3.}

${ }^{7}$ Finochiaro and Bonomo, The Foreign Language Learner: a Guide for Teacher (New York: Regents Publishing Company, Inc., 1973), hlm. 119. 
membaca, kita membuat bunyi dalam kerongkongan kita. Kita membaca lebih cepat kalu kita tahu bagaimana cara mengatakan serta mengelompokkan bunyi-bunyi tersebut dan kalau kita tidak tertegun-tegun melakukannya. Oleh karena itu, sangat penting sekali diingat agar setiap kesulitan yang berkenaan dengan bunyi, urutan bunyi, intonasi, atau jeda haruslah dijelaskan sebelum para pelajar disuruh membaca dalam hati maupun lisan. ${ }^{8}$. Kesimpulan yang dapat di tarik dari pembicaraan di atas adalah bahwa" membaca ialah memahami pola-pola bahasa dari gambaran tertulisnya".

\section{Tujuan Membaca}

Tujuan utama dalam membaca adalam untuk mencari serta memperoleh informasi, mencakup isi, memahami makna bacaan. Makna, arti (meaning), erat sekali berhubungan dengan maksud tujuan, atau intensif kita dalam membaca. Berikut ini kita kemukakan yang penting.

a. Membaca untuk menemukan atau mengetahui penemuanpenemuan yang telah dilakukan oleh tokoh; apa-apa yang telah dibuat oleh tokoh;apa yang telah terjadi pada tokoh khusus, atau untuk memecahkan masalah-masalah yang dibuat oleh tokoh. Membaca seperti ini disebut membaca untuk memperoleh perincian-perincian atau fakta-fakta (reading for details or facts).

b. Membaca untuk mengetahui mengapa hal itu merupakan topik yang baik dan menarik, masalah yang terdapat pada cerita, apa-apa yang dipelajari atau yang dialami tokoh untuk mencapai tujuannya. Membaca seperti ini disebut membasa untuk mendapat ide utama (reading for mein ideas).

c. Membaca untuk menemukan atau mengetahui apa yang terjadi pada setiap bagian cerita, apa yang terjadi mulamula pertama, kedua, dan ketiga/seterusnya, setiap tahap dibuat untuk memecahkan masalah, adegan-adegan dan

${ }^{8}$ Ibid., hlm. 120.

${ }^{9}$ Lado, Language Teaching: a Scientific Approach (Bombay-New Delhi: Tata Mc-Graw-Hill Publishing Co., Ltd., t.t.), hlm. 132. 
kejadian, kejadian buat dramatisasi. Ini disebut membaca untuk mengetahui urutan atau susunan, organisasi cerita (reading for sequence or organization).

d. Membaca untuk menemukan serta mengetahui mengapa para tokoh merasakan seperti cara mereka itu, apa yang hendak diperlihatkan oleh pengarang pada para pembaca, mengapa para tokoh berubah, kualitas-kualitas yang dimiliki para tokoh yang membuat mereka berhasil atau gagal, ini disebut membaca untuk menyimpulkan (reading for inference).

e. Membaca untuk menemukan serta mengetahui apa-apa yang tidak biasa, tidak wajar mengenai seorang tokoh, apa yang lucu dalam cerita, atau apakah cerita itu benar atau tidak benar. Ini disebut membaca untuk mengelompokkan, membaca untuk mengklasifikasikan (reading for classify).

f. Membaca untuk menemukan apakah tokoh berhasil atau hidup dengan ukuran-ukuran tertentu, apakah kita ingin berbuat seperti yang diperbuat seperti tokoh, atau bekerja seperti para tokoh bekerja dalam cerita itu. Ini disebut membaca menilai, membaca mengevaluasi (reading to evaluate).

g. Membaca untuk menemukan bagaimana caranya tokoh berubah, bagaimana hidupnyaberbeda darikehidupan yang kita kenal, bagaimana ada cerita mempunyai persamaan, dan bagaimana tokoh menyerupai membaca. Ini membaca untuk memperbandingkan atau mempertenangkan (reading to compare or contrast). ${ }^{10}$

\section{Pengertian Pembinaan dan Pengembangan Minat Baca}

Menurut Ibrahim Bafadal, pembinaan dan pengembangan minat baca adalah usaha memelihara, mempertahankan, dan meningkatkan minat baca. ${ }^{11}$ Minat baca seluruh pengunjung atau pemakai perpustakaan.

10Anderson, Language Skills in Elementary Education (New York: MacMillan Publishing Co., Inc., 1972), hlm. 214.

${ }^{11}$ Ibrahim Bafadal, Pengelolaan Perpustakaan Sekolah (Jakarta: Bumi 
Berbicara tentang membaca sebagai sebuah aktivitas yang sudah ada sejak berabat-abat silam, tentu ada manfaat di balik aktivitas tersebut. Sehingga seseorang ingin terus melestarikan aktivitas membaca. Terdapat empat belas manfaat membaca. Di antaranya adalah sebagai berikut.

a. Mempermudah memahami berbagai mata kuliah. Dengan membaca, mahasiswa dapat menambah, memperluas, dan memperdalam pelajaran yang telah diperoleh,dengan demikian, wawasan dan cakrawala berfikir lebih baik.

b. Mempertinggi kemampuan mahasiswa dalam membandingkan, meneliti, dan mempertajam pelajaran yang sudah didapatnya di kelas.

c. Meningkatkan apresiasi seni sastra dan seni-seni lainnya. Dengan membaca, mahasiswa meningkatkan kemampuan untuk menikmati berbagai karya seni.

d. Meningkatkan kemampuan untuk mengenal siapa dirinya dan mengenal lingkungannya yang lebih luas.

e. Meningkatkan keterampilan dan memperluas minat terhadap berbagai kegemaran dan aktivitas yang bermanfaat bagi pengembangan pribadi. Contohnya adalah dalam hal berbisnis.

f. Mengembangkan watak dan pribadi yang baik.

g. Meningkatkan selera dan kemampuan dalam membedakan yang baik dan yang buruk.

h. Mengisi waktu luang dengan kegiatan yang positif.

i. Mendidik untuk belajar mandiri. Dengan membaca, mahasiswa dapat mempelajari sesuatu secara mandiri.

j. Menambah perbendaharaan kata.

k. Mendidik untuk berfikir kritis dan mengetahui (well informed) berbagai permasalahan yang terjadi di lingkungannya, baik lingkungan sekitar maupun lingkungan yang lebih luas.

1. Memicu timbulnya ide baru.

$\mathrm{m}$. Memperluas pengalamam.

Aksara, 2009), hlm. 89. 
n. Sarana rekreasi yang mudah dan murah. Dengan membaca, buku-buku yang di gemarinya, mahasiswa dapat berekreasi dangan mudah dan murah. Buku-buku yang mengandung unsur rekreasi akan memberikan kesegaran dan kebahagiaan bagi mahasiswa.

\section{Memahami Prinsip-prinsip Membaca}

Beberapa prinsip membaca menurut Ibrahim Bafadal adalah sebagai berikut. ${ }^{12}$

a. Membaca merupakan proses berpikir yang kompleks. Karena sebagai proses berfikir yang kompleks, maka untuk membaca efisien, selain memiliki ketrampilan-ketrampilan sebagaimana di jelaakan sebelumnya, pembaca perlu memiliki kondisi fisik yang baik. Sehingga, konsentrasi tercurahkan sepenuhnya kepada teks atau tulisan yang sedang dibaca.

b. Kemampuan membaca setiap orang tidak sama. Maka pendidik pustakawan harus mengetahui kecerdasan, keadaan fisik, dan hubungan sosial setiap mahasiswanya, baik di kampus maupun di luar kampus. Selain itu, pendidik harus mengetahui sikap, aspirasi, dan kebutuhan setiap peserta didiknya. Sehingga kegiatan pembinaan dan pengembangan minat baca dapat disesuaikan dengan sifatsifat yang di miliki oleh setiap mahasiswa.

c. Pembinaan kemampuan membaca atas dasar evaluasi.

d. Membaca harus menjadi pengalaman yang memuaskan. Karena harus menjadi pengalaman memuaskan, maka pendidik, pustakawan hendaknya menyediakan bukubuku yang sesuai dengan kebutuhan mahasiswa.

e. Kemahiran membaca perlu latihan yang kontinu.

f. Evaluasi yang kontinu dan komprehensif adalah batu loncatan dalam pembinaan minat baca.

g. Membaca yang baik adalah syarat mutlak keberhasilan belajar.

${ }^{12}$ Ibid., hlm. 194-198. 


\section{Karakteristik Membaca yang Menyenangkan}

Ibrahim Bafadal mengungkapkan bahwa paling tidak, ada sebelas ciri khas atau atau karakretistik membaca yang menyenangkan sehingga menghasilkan sebuah aktivitas yang bermakna dan bermanfaat bagi mahasiswa. Di antaranya adalah sebagai berikut.

a. Ada tujuan yang ditetapkan sebelum membaca.

b. Selama kegiatan membaca berlangsung, selalu menerapkan beberapa teknik dan ketrampilan membaca dengan harapan semakin lama semakin mahir.

c. Mampu menafsirkan berbagai peta, gambar, daftar, dan grafik, serta dapat menggunakan alat-alat penunjuk penelusuran buku-buku.

d. Seseorang yang membaca harus mempunyai latar belakang pemahaman sehingga dapat lebih mudah mengerti materi yang sedang dibacanya.

e. Seorang membaca yang baik membentuk sikap-sikap tertentu sebagai hasil pemahaman terhadap bahan yang sedang dibacanya.

f. Seorang meembaca yang baik selalu mengembangkan minat bacanya sebagaimana membina dan mengembangkan kemampuan bacanya.

g. Seorang pembaca yang baik tanpa tergantung pada orang lain. Ia selalu berusaha sepenuhnya menggunakan kemampuan sendiri.

h. Seorang pembaca yang baik harus bisa membaca dengan kritis, baik kritis dalam membaca dan memahami materi, faktual, terutama materi yang disusun untuk memengaruhi pembaca, maupun materi yang bersifat opini.

i. Seorang pembaca yang baik selalu melihat atau mengamati hubungan antara bahan yang sedang dibaca dengan masalah yang sedang dihadapi.

j. Seorang pembaca yang baik selalu mengorganisasi konsep dari berbagai sumber dan membuat aplikasi praktis dari yang sedang dibacanya. 
k. Seorang pembaca yang baik harus bisa membaca dengan penuh kenikmatan. Ia bisa duduk dengan santai dan memperoleh kesenangan dalam membacanya.

\section{Faktor-faktor Kesiapan Membaca}

Kesiapan adalah suatu keadaan atau kondisi yang dapat meningkatkan keberhasilan membaca dan belajar. Dalam membina dan mengembangkan minat bacamahasiswa, pustakawan sangatperlu memperhatikan hal ini.

Ada sejumlah faktor yang turut menentukan terhadap kesiapan mahasiswa dalam membaca dan belajar. Kesemuanya dikelompokkan menjadi empat hal, di antara kesiapan mental (mental readiness for reading), kesiapan fisik ( physical readiness for readng), kesiapan emosi (emotional readiness for reading), dan kesiapan pengalaman (experiential readiness for reading).

Terkait dengan kesiapan mental, dapat di jelaskan bahwa seseorang yang mentalnya cukup matang atau sehat maka akan terhindar dari gangguan jiwa, hatinya tenang, tenteram, dan bahagia. Ia pun dapat memanfaatkan segala potensi dan bakatnya dengan sangat maksimal. Namun, apabila mentalnya kurang sehat, akan timbul beberapa gejala, misalnya sering lupa, kemampuan berpikir menurun, sulit berkonsentrasi, dan lain sebagainya.

Kemudian, berhubungan dengan kesiapan fisik, ada beberapa faktor yang mempengaruhi keberhasilan membaca. Di antaranya, berhubungan dengan kapasitas atau kemampuan penglihatan dan pendengaran. Seseorang yang lemah penglihatannya tidak akanbisa melihat dengan jelas apa yang dibacanya. Sehingga, sebagai akibatnya, orang tersebut akan mengalami kesulitan membaca.

Sementara itu, berkenaan dengan kesiapan emosi, maka gangguan emosi dapat pula mempengaruhi keberhasilan membaca dan belajar.Seperti seorang anak yang memiliki sifat pemalu, terlalu penakut, menunjukkan kesulitan emosi. Pada akhirnya, kondisi itu menjadikannya kesulitan membaca dengan baik.

Dan terakhir, dan berkaitan dengan pengalaman. Maksudnya disinipernahatautidaknya membaca, seringatau tidaknyamembaca, 
luas atau tidaknya pengetahuan yang dimiliki, semua itu sangat mempengaruhi kesiapan membaca dan belajar mahasiswa. Sebagai contoh, mahasiswa yang memiliki latar belakang pengetahuan yang luas akan lebih cepat memahami bacaan daripada mahasiswayang kurang memiliki latar belakang pengetahuan.

\section{Pemanfaatan Perpustakaan untuk Meningkatkan Motivasi Membaca pada Mahasiswa}

a. Upaya yang Dilakukan oleh Pustakawan di Perguruan Tinggi

Salah satu tugas pustakawan dalam rangka memfungsikan perpustakaan sebagai pusat sumber belajar adalah membangkitkan rasa senang dan tertarik untuk membaca pada para mahasiswa. Sebab, apabila pada diri mahasiswa sudah muncul rasa senang membaca, ia akan senang membaca dan memanfaatkan perpustakaan dengan maksimal.

Ada beberapa upaya yang bisa dilakukan oleh pustakawan sekolah untuk membangkitkan rasa senang dan gairah membaca para mahasiswa.

Pertama, memperkenalkan buku-buku. Cara ini bisa dilakukan oleh pendidik pustakawan dengan jalan bekerja sama dengan pengajar mata kuliah. Jadi, biarkan para pengajar tersebut memanfaatkan koleksi pustaka yang dimiliki oleh perpustakaan sebagai bahan ajar. Dengan demikian, jika mahasiswa tertarik, ia akan berkunjung ke perpustakaan.

Kedua, memperkenalkan riwayat hidup para tokoh. Pada cara ini, yang perlu ditekankan adalah sewaktu memperkenalkan, yaitu kegigihan tokoh-tokoh tersebut daalm hal membaca, belajar mandiri untuk menambah pengetahuan sehingga menjadi tokoh yang besar dan mashur.

Ketiga, memperkenalkan hasil-hasil karya para sastrawan. Sementara itu, untuk cara ini, dapat dilakukan dengan memperkenalkan sastrawan-sastrawan Indonesia dengan berbagai mahakarya yang dihasilkannya. Dengan demikian, mahasiswabisa mengenaliberbagai karya mereka. 
Keempat, dengan cara menyelenggarakan display dan pameran buku. Cara ini dilakukan dengan menempatkan dan menyusun buku-buku perpustakaan dengan posisi yang mencolok, sehingga membuat para mahasiswa tertarik untuk melihat. Itulah beberapa cara yang dapat dilakukan untuk meningkatkan minat baca para mahasiswa.

Cara lainnya adalah dengan memperbesar peranan pendidik dalam membangkitkan minat baca mahasiswa. Dalam hal ini, ada beberapa upaya yang dapat dilakukan. Pertama, perlu perbaikan metode belajar dan mengajar yang selama ini bersifat texsbooks centered kepada metode yang lebih membuka kemungkinan penggunaan bahan bacaan yang lebih luas dan bervariasi. Kedua, memberikan motivasi membaca kepada anak didik dengan pelaksanaan ulangan-ulangan. Ketiga, memberikan kebiasaan yang intensif sejak awal.

Keempat, melengkapi koleksi perpustakaan dengan bahanbahan bacaan yang menarik dan bermanfaat sesuai dengan kurikulum. Pengadaan bahan bacaan yang sesuai dengan selera (teste), kebutuhan (needs), dan tuntutan (demand) bisa menambah intensitas anak didik untuk berkunjung ke perpustakaan. Kelima, seorang pendidik bisa saja bekerja sama dengan pustakawan dalam mempromosikan cara mendayagunakan perpustakaan dengan benar, bahan-bahan apa saja yang ada di perpustakaan koleksi apa saja yang dianggap menarik dan baru, dan lain sebagainya. Keenam, pendidik bisa menanamkan kebiasaan membaca kepada mahasiswa melalui pemberian tugas-tugas membuat kliping, membuat karya ilmiah, ringkasan bab atau ringkasan buku-buku sastra, dan lain sebagainya.

\section{b. Macam-macam Perpustakaan yang Disediakan 1) Aplikasi IT Perpustakaan}

Seiring dengan perjalanan waktu, perkembangan information and technology (IT) semakin besar. Perkawinan antara perpustakaan dengan dunia IT dalam pelayanan yang diberikan kepada pengguna adalah sesuatu yang harus dilakukan. Maka dari itu, salah satu strategi pengembangan perpustakaan di era global sekarang perlu 
dikembangkan. Bagi yang sudah menggunakannya, berarti harus dilestarikan dan ditingkatkan, yaitu otomatisasi perpustakaan.

Seperti dijelaskan oleh Lasa $\mathrm{HS},{ }^{13}$ untuk meningkatkan kinerja perpustakaan sekolah, kiranya perlu dipikirkan otomasi perpustakaan. Otomasi perpustakaan sebenarnya merupakan proses atau hasil penciptaan mesin swatindak atau swakendali dalam proses tersebut. Penerapan otomatimasi perpustakaan sekolah sebenarnya lebih rapat apabila disebut dengan teknologi informasi. Yaitu, teknologi elektronik yang digunakaan untuk pengumpulan, penyimpanan, pengolahan, dan pemanfaatan informasi. Dalam hal ini, tidak hanya terbatas pada pemanfaatan perangkat lunak atau perangkat keras, tetapi juga melibatkan unsur manusia.

Adapun pemanfaatan teknologi informasi untuk kegiatan perpustakaan yang dimiliki beberapa tujuan. Pertama, meringankan pekerjaan. Kedua, memudahkan dan memperlancar pelaksanaan tugas kepustakawanan. Ketiga, mempercepat temu kembali akan informasi. Keempat, memperlancar kerja sama informasi. Kelima, meningkatkan pelayanan informasi dan memanfaatkan teknologi informasi.

Teknologi informasi dapat diaplikasikan pada kegiatan pengadaan, inventarisasi, katalogisasi, sirkulasi, bibliografi, pengindeksan, dan penelusuran literature. Diakui bahwa pemanfaatan IT ini memerlukan biaya tinggi. Untuk itu, perlu dilakukan studi kelayakan, rancang bangun, implementasi, dan evaluasi. Contoh teknologi informasi dalam kegiatan perpustakaan yang telah terintegrasi di antaranya kegiatan inventarisasi, katalogisasi, penelusuran informasi, peminjaman, dan pengembalian buku yang tekah berjalan otomatis. Dalam sistem ini, pengguna dapat melakukan fotokopi sendiri. Mereka lebih dulu mengisikan kartu langganan untuk sejumlah tertentu, seperti voucer pada handphone. Para pemakai juga bisa bebas mem-browsing internet di sana. Mereka bisa men-download artikel tertentu atau mencetak pada public printer yang tersedia. Setelah selesai proses peminjaman

13 Lasa HS, Manajemen Perpustakaan (Yogyakarta: Pinus, 2008), hlm. 215 . 
tersebut, peminjam keluar melewati pintu ber-alarm yang berfungsi sebagai pengontrol dan mencatat pengunjung secara otomatis.

\section{2) Perpustakaan Digital}

Perubahan yang terjadi dari zaman ke zaman telah mengantarkan manusia ke era digital, suatu era yang sering kali menimbulkan pertanyaan, apakah kita masih hidup di masa kini atau telah hidup di masa yang akan datang. Teknologi komunikasi dan informasi atau teknologi telematika (ICT) telah diakui sebagai salah satu saranadan prasarana utuama untuk mengatasi masalahmasalah dunia. Perkembangan terkini dalam dunia teknologi dan informasi dan komunikasi mengalami perubahan yang signifikan, tidak terkecuali dengan perpustakaan. Perpustakaan telah berabadabad terkukung dalam koleksi tercetak, baik buku, jurnal, maupun majalah. Informasi yang disimpan dalam perpustakaan berupa catatan-cacatan. Sistem temu kembali informasinya pun belum terotomatisasi dan masih menggunakaan sistem manusia. Saat ini, zaman menuntut lain. Koleksi perpustakaan dituntutdalam bentuk digital, padahal sistem konvensional sudah meruah jumlahnya. Namun, jika pada era globalisasi ini tidak mengubah wajah konvensionalnya, nilai juang perpustakaan tersebut akan berkurang, atau mungkin suatu ketika harus siap di tinggalkan oleh penggunaanya. Suatu hal yang menarik pada era globalisasi ini perpustakaan dikatakan sebagai era digital. Maka, muncullah konsep digital library, digital library, yang koleksinya mengarah pada e-journal, e-book, dan sejenisnya.

Menurut Wiji Suwarno, perpustakaan digital adalah perpustakaan yang mampu melayani penggunanya dengan segala kemudahan. ${ }^{14}$ Perpustakaan adalah suatu sistem yang menyediakan suatu komunitas pengguna dengan akses terintregasi yang menjangkau keluasan informasi dan ilmu pengetahuan yang tersimpandan terorganisasi dangan baik. Menurut Brogman, sebagaimana dikutip Suwarno, lebih jelas definisi tentang perpustakaan digital muncul dari praktisi perpustakaan Digital

14 Wiji Suwarno, Pengetahuan Dasar Kepustakaan (Bogor: Ghalia Indonesia, 2010), hlm. 38-39. 
Library Federation (DLF), ia menyatakann bahwa perpustakaan digital adalah organisasi yang menyediakan sumber daya mencakup mencakup staf ahli untuk memiliki struktur; penawaran akses intelektual untuk menginterpretasikan, mendistribusikan, memelihara integritas, dan koleksi dari waktu ke waktu sedemikian rupa, sehingga tersedia dan siap digunakaan oleh masyarakat.

\section{3) Perpustakaan Hybird}

Menurut Wiji Suwarno, solusi terbaik untuk mengatasi paradok perpustakaan digital adalah menggabungkan unsure keduanya (sistem konvensional dan sistem digital) dalam satu perpustakaan. ${ }^{15}$ Itulah yang disebut "perpustakaan dua muka". Artinya, perpustakaan ini memiliki dan melayani dua jenis koleksi. Satu sisi, perpustakaan sekolah melayani koleksi digital, dan sisi yang lain, masih melayani dan memanfaatkan koleksi konvensional sebagai bahan rujukan yang tercetak. Jenis perpustakaan ini tampak lebih humanis, masih menjembatani pemakai perpustakaan sekolah yang memang tidak semuanya mengerti dan memahami koleksi dalam ranah digital. Adapun istilah yang popular untuk jenis perpustakaan hibrida atau hybrid library.

Brogman, sebagaimana dikutip Suwarno, menjelaskan bahwa perpustakaan hibrida didesain untuk mengelola teknologi dari dua sumber yang berbeda, yaitu sumber elekronik dan sumber tercetak. Perpustakaan ini dapat diakses melalui jarak dekat juga jarak jauh. Sementara itu, negara yang termasuk paling aktif melakukan penelitian pengembangan konsep perpustakaan hybrid adalah Inggris. Negara ini menyediakan lima proyek perpustakaan hibrida, yaitu BUILDE, AGORA, MALIBU, HeadLine, dan HyLife. Kelimanya merupakan bagian dari proyek e-lib.

Adapun yang perlu kita ketahui dari perpustakaan hibrida adalah kerja sama yang baik antara pustakawan para teknolog yang menyatukan keterpisahan tradisi sebagai konsekuensi perpustakaan hibrida, yang secara bersamaan membangun koleksi "baru" (elektronik atau digital) dan koleksi (tercetak) secara terintegrasi. Sehingga, pemakai jasa perpustakaan tidak mengalami kesulitan

${ }^{15}$ Ibid., hlm. 39-40. 
dalam memakai kedua jenis koleksi tersebut. Di sini, teknologi informasi dan jaringan telematika berperan sebagai fasilitas untuk mempertemukan kedua koleksi itu di perpustakaan. Perbedaan utama dari portal perpustakaan hibrida dari portal perpustakaan yang sepenuhnya digital adalah dalam dua hal, sebagai tercantum dalam tabel berikut.

Tabel Perbedaan Perpustakaan Hibrida dan Perpustakaan Digital

\begin{tabular}{|c|c|}
\hline Perpustakaan Hibrida & Perpustakaan Digital \\
\hline $\begin{array}{l}\text { Memiliki koleksi cetak yang } \\
\text { permanen dan setara dengan } \\
\text { koleksi elektronik atau digitalnya. } \\
\text { Perpustakaan hibrida juga } \\
\text { bermaksud mempertahankan } \\
\text { koleksi tercetak. }\end{array}$ & $\begin{array}{l}\text { Portal perpustakaan yang } \\
\text { sepenuhnya digital, tidak } \\
\text { memiliki koleksi tercetak } \\
\text { sama sekali. Perpustakaan } \\
\text { ini menganggap bahwa } \\
\text { koleksi tercetak sudah tidak } \\
\text { mewakili kemoderenan dan } \\
\text { keteknologian. }\end{array}$ \\
\hline $\begin{array}{l}\text { Perpustakaan hibrida memperluas } \\
\text { konsepdan cakupan jasa } \\
\text { informasi, sehingga menambah } \\
\text { koleksi elektronik komputer serta } \\
\text { penggunaan teknologi komputer } \\
\text { tidak dipisahkan dari jasa berbasis } \\
\text { tercetak. }\end{array}$ & $\begin{array}{l}\text { Penyempitan cakupan } \\
\text { informasi yang terbatas pada } \\
\text { koleksi yang digitalkan, atau } \\
\text { terdapat koleksiyang memang } \\
\text { sejak awal berbentuk digital. }\end{array}$ \\
\hline
\end{tabular}

Dalam konsep selanjutnya, menurut Suwarno, konsep perpustakaan hibrida juga dapat diperluas menjadi lingkungan informasi hibrida (hybrid invormation evironment). Di dalam lingkungan seperti ini, jenis koleksi bukan satu-satunya penentu karakteristik dari sebuah perpustakaan. Artinyaapapun jenis koleksinya, sebuah perpustakaan harus dapat mengembangkan suasana yang memungkinkan pemakai memanfaatkan koleksi tersebut. Apabila suatu saat perpustakaan tersebut memiliki lebih dari satu jenis koleksi, maka saat itulah perpustakaan tersebut memikirkan lingkungan campuran alias lingkungan hibrida. Jika penambahan koleksi yang baru itu adalah koleksi digital, maka koleksi lama dengan jenis lama tidak perlu disingkirkan, melainkan 
digabung menjadi bagian dalam satu layanan hibrida. Demikian seterusnya, ketika jenis koleksi diperluas menjadi koleksi jarak jauh maka koleksi lokal atau koleksi dekat tidak perlu dihapus, melainkan digabung lagi menjadi bagian dari lingkungan hibrida.

\section{4) Pengembangan Perpustakaan Sekolah Berpara- digma Kekinian}

Selain beberapa poin yang telah dibahas sebelumnya, satu poin penting lainnya yang tidak bisa kita lepaskan dari strategi pengembangan perpustakaan sekolah pada era global adalah perubahan paradigma. Seperti kita ketahui bahwa perkembangan zaman menuntut perubahan pola pikir masyarakat agar mampu beradaptasi dengan baik dalam situasi dan kondisi tertentu. Demikian dengan paradigma perpustakaan, dituntut mampu mengikutiperkembangan ilmu pengetahuan dan teknologi. Terdapat beberapa paradigma perpustakaan yang berbasis kekinian. ${ }^{16}$

Pertama, simpan saji karya. Yaitu, fungsi perpustakaan sebagai tempat penyimpanan suatu karya, yang kemudian menjadikan karya tersebut sebagai informasi yang dapat di akses penggunanya. Sebagaimana diatur dalam UU No. 43 Tahun 2007 bahwa koleksi perpustakaan diseleksi, dilayankan, disimpan, dan dikembangkan sesuai dengan kepentingan pengguna.

Kedua, pusat sumber daya informasi (SDI). Yaitu, fungsi perpustakaan yang menggali dan mengelola informasi, yang dapat menjadi bahan bagi pengguna untul menghasilkan karya baru yang dapat diakses oleh pengguna lainnya sebagai informasi baru. Sebagai man yang tertuang dalam UU No. 43 Tahun 2007, koleksi perpustakaan diseleksi, dilayankan, disimpan, dan dikembangkan sesuai dengan kepentingan pemustaka, serta memperhatukan perkembangan teknologi informasi dan komunikasi. Dalam hal ini terdapat dua pesan bagi pustakawan, yaitu mengembangkan sistem pencari (kelola informasi) dan tanggap terhadap informasi baru.

16 Andi Prastowo, Manajemen Perpustakaan Sekolah Profesional (Yogyakarta: Diva Press), hlm. 397. 
Ketiga, pusat sumber belajar atau penelitian mesyarakat, yaitu fungsiperpustakaan sebagaitempatbelajar dan penelitianmasyarakat sehingga menjadi masyarakat yang cerdas dan berpengetahuan luas. Hal itu termaktub dalam Pasal 2 UU No. 42 Tahun 2007 yang menyebutkan bahwa perpustakaan diselenggarakan berdasarkan asas pembelajaran sepanjang hayat. Dalam ayat lainnya pun diterangkan bahwa perpustakaan bertujuan memberikan layanan kepada pemustaka, serta memperluas wawasan dan pengetahuan untuk mencerdaskan kehidupan bangsa.

Keempat, rekreasi dan re-kreasi. Yaitu, fungsi perpustakaan sebagai tempat yang nyaman serta menyajikan informasiinformasi yang bersifat menyenangkan, serta sebagai tempat yang menghasilkan kreasi (karya) baru yang berpijak dari karya-karya orang lain yang telah dipublikasikan.

Kelima, mengembangkan budaya. Maksudnya, fungsi perpustakaan sebagai tampat mengembangkan kebudayaan melalui informasi yang disajikan, serta penanaman nilai-nilai pada masyarakat melalui berbagai kegiatan. Contohnya, pemutaran film, belajar menari, dan lain sebagainya.

Keenam, pelayanan yang berorientasi pelanggan. Maka, slogan pelayanan yang perlu dikembangkan di perpustakaan sekolah adalah 4 S, yaitu senyum, sapa, sopan, dan santun.

Satu hal yang perlu ita ingat adalah sasaran perpustakaan ke depan. Jonathan Hey, sebagaimana dikutip oleh Suwarno, mengungkapkan bahwa perpustakaan bertugas mencari berbagai data, kemudian data tersebut diseleksi dan dikelola sedemikian rupa, sehingga menjadi suatu informasi yang layak saji untuk kepentingan penggunanya.

Lebih dari satu, informasi yang di akses oleh pengguna menjadi suatu pengetahuan yang berguna bagi para penggunanya. Harapanya, ketika pengguna sudah memiliki ilmu pengetahuan, maka ia diharapkan menjadi bijaksana dalam memilih data, memilih informasi, menentukan sikap. Maupun dalam mengambil keputusan. Apabila hidup seseorang berlandaskan kebijaksanaan, dapat dikatakan ia telah menjadi orang-orang terdidik(tercerahkan), 
yaitu memiliki pengetahuan dan wawasan yang luas, jika sasaran perpustakaan ke depan adalah demi mewujudkan masyarakat yang berpendidikan, tentu ini dapat diwujudkan. Tentang hal ini perhatikan gambar berikut.

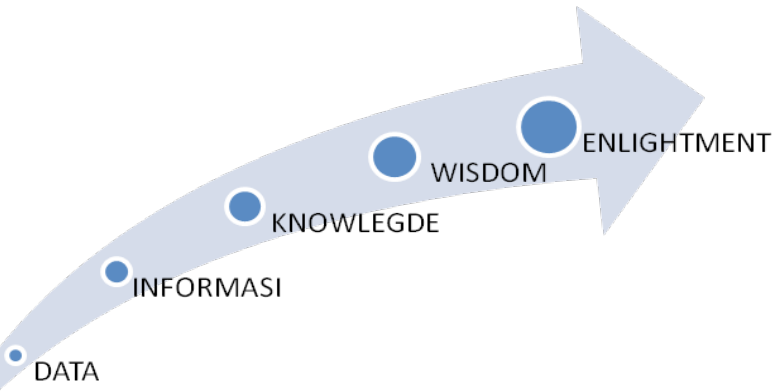

Gambar Sasaran Perpustakaan Sekolah Masa Depan

\section{Simpulan}

Demikian tadi paparan pemanfaatan perpustakaan di perguruan tinggi untuk meningkatkan motivasi membaca mahasiswa. Harapan untuk ke depan, perpustakaan semakin lebih baik dalam pelayanan kepada pengunjung dan menyediakan tempat yang nyaman, serta mampu menyediakan layanan yang cepat, untuk menunjang kebutuhan para pengunjung, sehingga persentase pengunjung perpustakaan meningkat, dan motivasi membaca di perpustakaan semakin meningkat pula. 


\section{DAFTAR PUSTAKA}

Anderson. Language Skills in Elementary Education. New York:

MacMillan Publishing Co., Inc., 1972.

Bafadal, Ibrahim. Pengelolaan Perpustakaan Sekolah. Jakarta: Bumi Aksara, 2009.

Finochiaro and Bonomo. The Foreign Language Learner: a Guide for Teacher. New York: Regents Publishing Company,Inc., 1973.

Hodgson, FM. Learning Modern Languages. London: Routledge and Hegan Paul, t.t.

Lado. Language Teaching: a Scientific Approach. Bombay-New Delhi: Tata Mc-Graw-Hill Publishing, Co., Ltd., 1976.

Lasa HS. Manajemen Perpustakaan. Yogyakarta: Pinus, 2008.

Mustopa, Halmar. Strategi Belajar Mengajar. Semarang: Universitas Islam Sultan Agung, 2006.

Prastowo, Andi. Manajemen Perpustakaan Sekolah Profesional. Yogyakarta: Diva Press, 2012.

Sardiman, AM. Interaksi dan Motivasi Belajar Mengajar. Jakarta: Rajawali Press, 1988.

Suryabrata, Sumadi. Psikologi Pendidikan. Jakarta: RajaGrafindo Persada, 2004.

Suwarno, Wiji. Pengetahuan Dasar Kepustakaan. Bogor: Ghalia Indonesia, 2010. 
Halaman ini bukan sengaja dikosongkan 